\title{
ПОРІВНЯЛЬНА ХАРАКТЕРИСТИКА ПРОЦЕСІВ ОСТЕОРЕГЕНЕРАЦІЇ ПРИ ЗАСТОСУВАННІ МАТЕРІАЛУ НА ОСНОВІ ГІДРОКСИАПАТИТУ ТА ПОЛІЛАКТИДУ
}

\section{ДВНЗ «Тернопільський державний медичний університет імені І. Я. Горбачевського МОз України»}

РЕЗЮмЕ. Вступ. Остеорегенерація при відновленні кісткових дефектів щелеп є важливим питанням сучасної стоматології. Незважаючи на численні опубліковані праці, ідеального матеріалу все ще не існує, тому його пошук $\epsilon$ актуальним.

Мета дослідження. Вивчення процесів остеорегенерації шляхом оцінювання маркерів обміну колагену та проведення порівняльного аналізу репарації в кореляції з рентгенологічними даними на 180 добу експерименту.

Матеріал і методи. Експеримент проведено на білих щурах-самцях масою 180-200 г. Під загальним знеболюванням тваринам створювали наскрізний отвір у ділянці щелепи. У контрольній групі загоєння відбувалось лише під кров'яним згортком, а у дослідних групах кістковий дефект заміщувався матеріалом на основі гідроксиапатиту та полілактиду з різним відсотковим вмістом компонентів (1 група (80:20 \%); 2 група (50:50 \%)). Окремо була виділена група інтактних тварин, яким втручання не проводили, а лише здійснювали забір сечі для порівняльного дослідження.

Рентгенологічне дослідження вилучених щелеп проводили за допомогою цифрового радіовізіографа Intra (Фінляндія).

Результати. В усіх випадках після пошкодження відбуваються процеси деструкції, що тривають до 7 діб. У контрольній групі спостерігається повільна їх зворотня тенденція, а збалансування відбувається лише на 90 добу, досягнення фізіологічного гомеостазу - на 180 добу.

У 1 дослідній групі переважання синтетичних процесів над деструкцією відмічається на 30 добу, а у віддалені терміни (90 та 180 доба) надалі відбувається домінування процесу катаболізму над анаболізмом.

У 2 дослідній групі домінування процесів синтезу колагену пришвидшується та відмічається вже на 21 добу, а кінцеве завершення остеорегенерації спостерігається на 180 добу.

Дані, отримані при оцінці рентгенограм нижніх щелеп тварин, корелювали з даними біохімічного дослідження.

Висновки. Заповнення кісткових дефектів запропонованими остеоімплантатами змінює перебіг регенерації. Встановлено, що виповнення дефекту резорбуючим композитом зменшує деструктивні процеси та пришвидшує формування первинної та вторинної кісткової мозолі. У цьому відношенні ефективнішою виявилась композиція з однаковим вмістом обох її складових.

КлючовІ словА: кістковий дефект; регенерація кісткової тканини; гідроксиапатит; полілактид; вільний оксипролін; білковозв'язуючий оксипролін.

Вступ. Досить часто у клінічній практиці доводиться мати справу з кістковими дефектами щелепових кісток. Причинами їх виникнення можуть бути травми, дифузні патологічні процеси (остеомієліт, кістозні та пухлинні утвори) та наслідки їх хірургічного лікування, які суттєво утруднюють протетичне лікування таких хворих $[1,2,3]$.

Високоефективним методом лікування таких станів $\epsilon$ застосування різноманітних кісткових замінників, які, завдяки своєму впливу, можуть помітно скорегувати процеси репаративної регенерації. Хоча питанням остеорегенерації присвячено велику кількість наукових досліджень, як вітчизняних, так і зарубіжних науковців, вказана проблема залишається не вирішеною [4-8].

Триває вивчення механізмів кісткової репаративної регенерації для розробки нових остеотропних пластичних матеріалів, здатних стимулювати процеси в кістковій тканині та забезпечувати сприятливі умови для відновлення повноцінної кістки [9-14].
Метою нашої роботи було вивчення процесів остеорегенерації шляхом оцінювання біохімічних показників, які $\epsilon$ маркерами обміну колагену як у контрольній групі (загоєння під кров'яним згортком), так і у двох дослідних групах, де кістковий дефект заміщувався остеопластичним матеріалом на основі гідроксиапатиту та полілактиду 3 різним відсотковим вмістом компонентів, та проведення порівняльного аналізу репарації в кореляції з рентгенологічними даними на 180 добу експерименту.

Матеріал і методи дослідження. Експеримент проведено на білих статевозрілих щурах-самцях масою 180-200 г. Тварин було поділено на групи: контрольну й 1 та 2 дослідні. Кожна група поділена на підгрупи залежно від термінів вилучення тварин з експерименту (по 6 тварин на термін). Усі маніпуляції з піддослідними тваринами здійснювали відповідно до міжнародних вимог згідно з «Європейською конвенцією захисту хребетних тварин, що використовуються для дослідних та інших наукових цілей» (Страсбург, 1986) та «За- 
Огляди літератури, оригінальні дослідження, погляд на проблему

гальних етичних принципів експериментів на тваринах», ухвалених Першим національним конгресом з біоетики (Київ, 2001). Оперативне втручання проводили під загальним знеболюванням. Для цього використовували 0,04 мл 5 \% розчину тіопенталу натрію, який вводили внутрішньоочеревинно в лівий нижній квадрант черевної порожни. Оперативне втручання здійснювали за загальновідомою методикою (Чечин А. Д., 1989 р.), дещо її модифікувавши. Після видалення шерстного покриву (проекція нижньої щелепи та підщелепна ділянка зліва) та обробки операційного поля 3 \% розчином йоду проводили розріз шкіри паралельно та нижче нижнього краю нижньої щелепи завдовжки 1-1,5 см. Далі тупим шляхом відсепаровували м'які тканини до кістки. За допомогою фізіодиспенсера SURGEC XT (NSK, Японія) при швидкості 800 об/хв з постійним охолодженням 0,9 \% розчином хлориду натрію створювали наскрізний отвір у ділянці кута нижньої щелепи зліва. Діаметр стоматологічного бора - 2 мм. У контрольній серії дослідів після антисептичної обробки рану ушивали. У 1 дослідній серії використовували імплантаційний матеріал (гідроксиапатит 80 \%+полілактид 20 \%), в 2 дослідній групі використовували імплантаційний матеріал (гідроксиапатит 50 \%+полілактид 50 \%). Для створення цієї композиції використовували полілактид (Poly (L-Lactide ) Purasorb PL 32 (Holland) та гідроксиапатит (ГА) Са10-х(РО 4) 6(ОН) 2 з розміром частинок 0,1 мм (температура спікання $=10500^{\circ} \mathrm{C}$ ), синтезований на кафедрі хімічної технології силікатів НУ «Львівська політехніка». Блокову (ко)полімеризацію композицій здійснювали у термошафі на повітрі за температури $348{ }^{\circ} \mathrm{K}$ протягом 4,5 год. Після закінчення синтезу полімерні зразки охолоджували до кімнатної температури впродовж 1,52 год. Виводили тварин з експерименту на 7, 14, 21, 30, 90, 180 доби шляхом передозування розчину тіопенталу натрію, який вводили внутрішньоочеревинно. Для проведення досліджень використовували сечу піддослідних тварин, яку збирали в переддень евтаназії. Лабораторно визначення вмісту фракції вільного та білковозв'язаного оксипроліну проводили за методом Шараєва П. Н. [15]; цей метод базувався на принципі осадження сумішшю трихлороцтової і хлорної кислот. Коефіцієнт фракційного співвідношення оксипроліну вираховували за відношенням визначених вмістів білковозв'язаного оксипроліну до вільного в тварин кожної піддослідної групи у всіх термінах дослідження.

Рентгенологічне дослідження проводили за допомогою цифрового радіовізіографа Intra (Фінляндія). Для дослідження використовували вилучені та відпрепаровані нижні щелепи щурів. Оцінювали стан дефекту, наявність чи відсутність імплантаційного матеріалу, візуальну щільність та структуру кісткової тканини.

Експериментальні дані обробляли за допомогою непараметричних методів статистики (критерію Вілкоксона). Розходження вважали достовірним при р>0,05.

Результати й обговорення. Колаген - фібрилярний білок сполучної тканини, на 90-95 \% формує органічний матрикс кістки будь-якого організму. Більше третини усіх амінокислот, що входять до складу кісткового колагену, припадає на пролін і оксипролін, які не зустрічаються в інших білках і мають безпосереднє відношення до репаративного остеогенезу [16].

Тому кількісне визначення оксипроліну характеризує стану обміну основного білка кістки - колагену. Концентрація вільної фракції оксипроліну (BO) $€$ показником катаболізму колагену, а рівень вмісту білковозв'язаного оксипроліну (БЗО) відображає його синтетичну складову $[16,17]$.

Отримані дані щодо вмісту ВО в сечі експериментальних тварин подано у таблиці 1 та на рисунку 1.

У тварин контрольної групи на 7 добу спостерігали достовірне зростання вмісту ВО до рівня $142,93 \%(p<0,05)$ щодо інтактних тварин. Подальша тенденція характеризувалася поступовим зменшенням цього значення. Достовірна різниця зберігалася впродовж 14, 21, 30, 90 діб. Вміст ВО в сечі тварин контрольної групи на 14 добу та 21 добу складав відповідно 125,91 \% (p<0,05) та 120,57 \% $(p<0,05)$. Починаючи з 30 доби, коли вміст ВО становив $117,12 \%(p<0,05)$, та у наступний термін (90 до6а; 104,34 \% з р<0,05) різниця до показника інтактних тварин була мінімальною та, як зазначалось вище, статистично достовірною. На завершення спостереження значення вмісту ВО відповідало межам фізіологічної норми та складало $101,04$ \% від початкового ( $>>0,05)$.

Вміст ВО в сечі тварин обох дослідних груп був відмінним від контрольної. На 7 добу в 1 дослідній групі спостерігалося достовірне зростання цього показника до 141,51 \% (р<0,05). Впродовж наступних трьох термінів відмічено кількісне зменшення вмісту ВО. На 14 та 21 доби ще зберігалася достовірна різниця зі значенням інтактних тварин - 130, 20 \% $(p<0,05)$ та 115,54\% ( $p<0,05)$ відповідно.

На 30 добу вміст ВО був статистично недостовірно більшим та становив відповідно 105,13\% (p>0,05). На відміну від контрольної, у тварин 1 дослідної групи на 90 добу виявлено повторне статистично достовірне зростання вмісту ВО на $121,98 \%(p<0,05)$. На завершення спостереження (180 доба) вміст ВО переважав його фізіологічний рівень на $116,49 \%(p<0,05)$. 
Огляди літератури, оригінальні дослідження, погляд на проблему

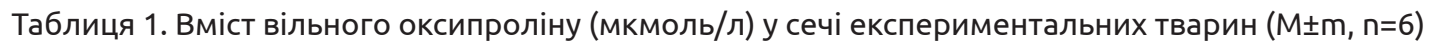

\begin{tabular}{|c|c|c|c|c|}
\hline \multirow{2}{*}{$\begin{array}{c}\text { Термін } \\
\text { спостереження } \\
\text { (доба) }\end{array}$} & \multicolumn{4}{|c|}{ Група тварин } \\
\hline & інтактні & контрольна & дослідна 1 & дослідна 2 \\
\hline 7 & $19,10 \pm 1,10$ & $\begin{array}{c}27,30 \pm 1,51 \\
p_{1}<0,05\end{array}$ & $\begin{array}{c}27,03 \pm 1,46 \\
p_{1}<0,05 \\
p_{2}>0,05\end{array}$ & $\begin{array}{c}27,03 \pm 1,83 \\
\mathrm{P}_{1}<0,05 \\
\mathrm{P}_{2}>0,05 \\
\mathrm{P}_{3}>0,05\end{array}$ \\
\hline 14 & $19,10 \pm 1,10$ & $\begin{array}{c}24,05 \pm 1,46 \\
p_{1}<0,05\end{array}$ & $\begin{array}{c}24,87 \pm 1,37 \\
p_{1}<0,05 \\
p_{2}<0,05\end{array}$ & $\begin{array}{c}23,05 \pm 1,33 \\
\mathrm{P}_{1}<0,05 \\
\mathrm{P}_{2}<0,05 \\
\mathrm{P}_{3}<0,05\end{array}$ \\
\hline 21 & $19,10 \pm 1,10$ & $\begin{array}{c}23,03 \pm 1,10 \\
p_{1}<0,05\end{array}$ & $\begin{array}{c}22,07 \pm 1,10 \\
p_{1}<0,05 \\
p_{2}<0,05\end{array}$ & $\begin{array}{c}20,63 \pm 1,28 \\
\mathrm{P}_{1}<0,05 \\
\mathrm{P}_{2}<0,05 \\
\mathrm{P}_{3}<0,05\end{array}$ \\
\hline 30 & $19,10 \pm 1,10$ & $\begin{array}{c}22,38 \pm 1,15 \\
p_{1}<0,05\end{array}$ & $\begin{array}{c}20,08 \pm 1,46 \\
p_{1}>0,05 \\
p_{2}<0,05\end{array}$ & $\begin{array}{c}20,26 \pm 1,19 \\
\mathrm{p}_{1}<0,05 \\
\mathrm{P}_{2}<0,05 \\
\mathrm{P}_{3}>0,05\end{array}$ \\
\hline 90 & $19,10 \pm 1,10$ & $\begin{array}{c}19,93 \pm 1,11 \\
p_{1}<0,05\end{array}$ & $\begin{array}{c}23,30 \pm 1,41 \\
P_{1}<0,05 \\
p_{2}<0,05\end{array}$ & $\begin{array}{c}19,75 \pm 1,18 \\
P_{1}>0,05 \\
P_{2}>0,05 \\
P_{3}<0,05\end{array}$ \\
\hline 180 & $19,10 \pm 1,10$ & $\begin{array}{c}19,30 \pm 1,06 \\
p_{1}>0,05\end{array}$ & $\begin{array}{c}22,25 \pm 1,19 \\
p_{1}<0,05 \\
p_{2}<0,05\end{array}$ & $\begin{array}{c}19,25 \pm 1,11 \\
\mathrm{p}_{1}>0,05 \\
\mathrm{P}_{2}>0,05 \\
\mathrm{P}_{3}<0,05\end{array}$ \\
\hline
\end{tabular}

Примітки: 1. р $_{1}$ - значення коефіцієнта достовірності порівняно з групою інтактних тварин;

2. $\mathrm{p}_{2}$ - значення коефіцієнта достовірності порівняно з контрольною групою;

3. $\mathrm{p}_{3}$ - значення коефіцієнта достовірності порівняно з дослідною групою 1.

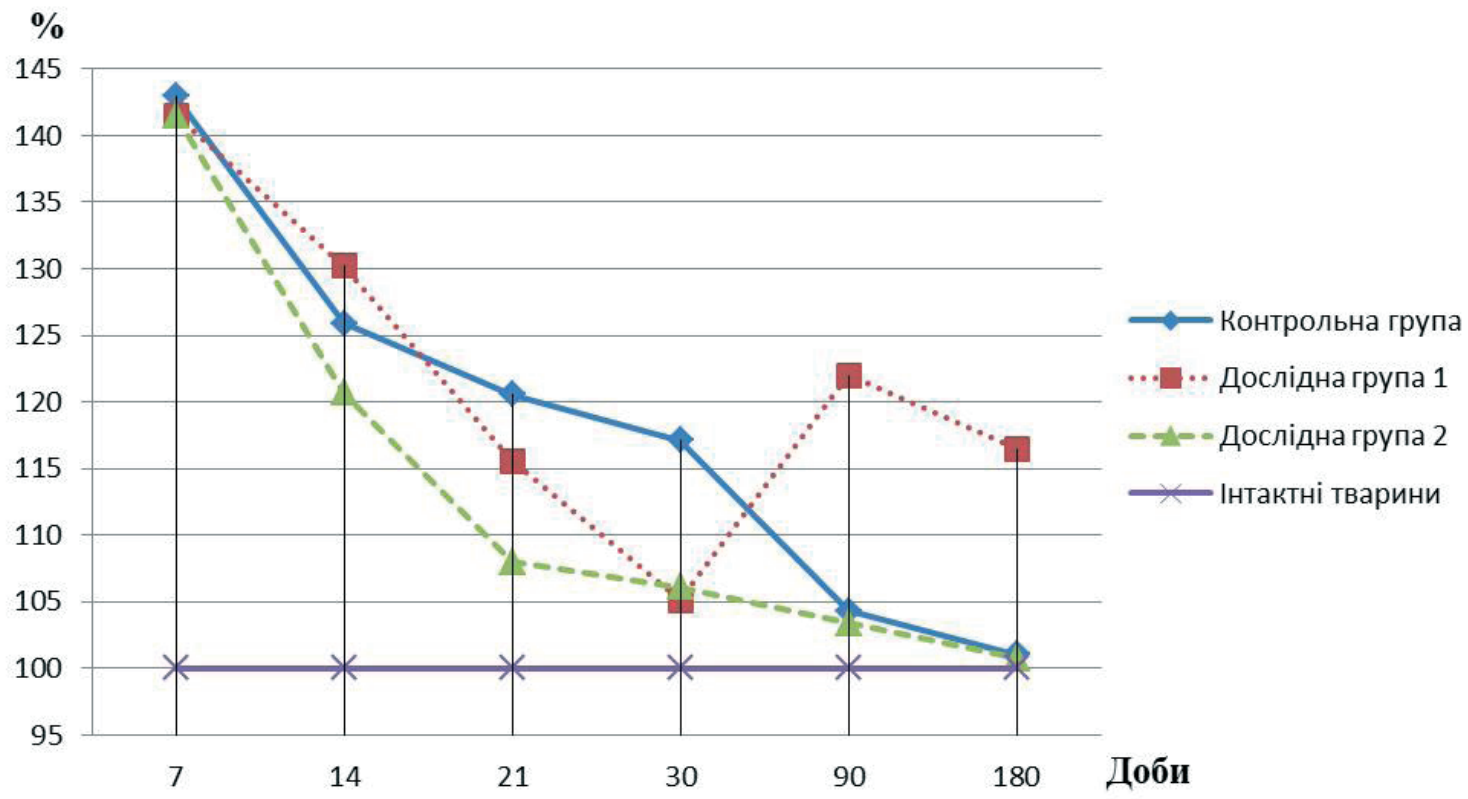

Рис. 1. Динаміка відсоткових значень вмісту вільного оксипроліну в сечі експериментальних тварин порівняно з показником інтактних щурів (100\%). 
Огляди літератури, оригінальні дослідження, погляд на проблему

Схожа картина, проте з дещо іншими цифровими показниками, була й у тварин 2 дослідної групи. Первинне зростання вмісту ВО на 7 добу складало $141,51 \%(p<0,05)$. Падіння цього вмісту до $120,68 \%(p<0,05)$ спостерігали на 14 добу. На 21 добу різниця до фізіологічних показників була теж достовірною та складала 108,01 \% $(p<0,05)$. У наступний термін спостерігали подальше повільне падіння, яке складало на 30 добу 106,07 \% ( $<<0,05)$. На 90 добу показник становив 103,40 \% та був статистично недостовірним ( $>>0,05)$. На завершення експерименту вміст ВО не відрізнявся від показника інтактних тварин та становив 100,78 \% (p>0,05).

За аналогічною схемою проводилося дослідження вмісту Б3О, цифрові та графічні дані яких викладено у таблиці 2 та на рисунку 2.

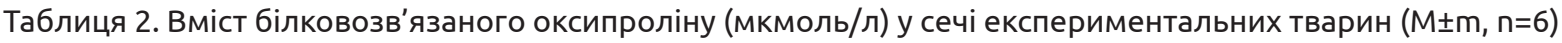

\begin{tabular}{|c|c|c|c|c|}
\hline \multirow{2}{*}{$\begin{array}{c}\text { Термін } \\
\text { спостереження } \\
\text { (доба) }\end{array}$} & \multicolumn{4}{|c|}{ Група тварин } \\
\hline & інтактні & контрольна & дослідна 1 & дослідна 2 \\
\hline 7 & $5,35 \pm 0,13$ & $\begin{array}{c}5,21 \pm 0,15 \\
P_{1}>0,05\end{array}$ & $\begin{array}{c}5,33 \pm 0,13 \\
\mathrm{P}_{1}>0,05 \\
\mathrm{P}_{2}<0,05\end{array}$ & $\begin{array}{c}5,30 \pm 0,11 \\
\mathrm{P}_{1}>0,05 \\
\mathrm{P}_{2}>0,05 \\
\mathrm{P}_{3}>0,05\end{array}$ \\
\hline 14 & $5,35 \pm 0,13$ & $\begin{array}{c}5,40 \pm 0,14 \\
\mathrm{P}_{1}>0,05\end{array}$ & $\begin{array}{c}5,72 \pm 0,22 \\
\mathrm{P}_{1}>0,05 \\
\mathrm{P}_{2}<0,05\end{array}$ & $\begin{array}{c}6,19 \pm 0,12 \\
\mathrm{P}_{1}<0,05 \\
\mathrm{P}_{2}<0,05 \\
\mathrm{P}_{3}<0,05\end{array}$ \\
\hline 21 & $5,35 \pm 0,13$ & $\begin{array}{c}5,50 \pm 0,18 \\
\mathrm{P}_{1}>0,05\end{array}$ & $\begin{array}{c}6,13 \pm 0,23 \\
\mathrm{P}_{1}<0,05 \\
\mathrm{P}_{2}<0,05\end{array}$ & $\begin{array}{c}5,86 \pm 0,16 \\
\mathrm{P}_{1}<0,05 \\
\mathrm{P}_{2}<0,05 \\
\mathrm{P}_{3}<0,05\end{array}$ \\
\hline 30 & $5,35 \pm 0,13$ & $\begin{array}{c}5,55 \pm 0,2 \\
P_{1}>0,05\end{array}$ & $\begin{array}{c}6,12 \pm 0,21 \\
\mathrm{P}_{1}<0,05 \\
\mathrm{P}_{2}<0,05\end{array}$ & $\begin{array}{c}5,52 \pm 0,15 \\
\mathrm{P}_{1}<0,05 \\
\mathrm{P}_{2}>0,05 \\
\mathrm{P}_{3}<0,05\end{array}$ \\
\hline 90 & $5,35 \pm 0,13$ & $\begin{array}{c}5,40 \pm 0,15 \\
P_{1}>0,05\end{array}$ & $\begin{array}{c}6,00 \pm 0,22 \\
\mathrm{P}_{1}<0,05 \\
\mathrm{P}_{2}<0,05\end{array}$ & $\begin{array}{c}5,71 \pm 0,15 \\
\mathrm{P}_{1}<0,05 \\
\mathrm{P}_{2}<0,05 \\
\mathrm{P}_{3}<0,05\end{array}$ \\
\hline 180 & $5,35 \pm 0,13$ & $\begin{array}{c}5,26 \pm 0,13 \\
p_{1}>0,05\end{array}$ & $\begin{array}{c}5,77 \pm 0,16 \\
\mathrm{P}_{1}<0,05 \\
\mathrm{P}_{2}<0,05\end{array}$ & $\begin{array}{c}5,34 \pm 0,10 \\
\mathrm{P}_{1}>0,05 \\
\mathrm{P}_{2}>0,05 \\
\mathrm{P}_{3}<0,05\end{array}$ \\
\hline
\end{tabular}

Примітки: 1. $\mathrm{p}_{1}$ - значення коефіцієнта достовірності порівняно з групою інтактних тварин;

2. $\mathrm{p}_{2}$ - значення коефіцієнта достовірності порівняно з контрольною групою;

3. р $_{3}$ - значення коефіцієнта достовірності порівняно з дослідною групою 1.

Рівень БЗО у тварин контрольної групи впродовж усіх термінів спостереження змінювався в незначній мірі. На 7 добу виявлено статистично недостовірне незначне його падіння до $97,38 \%$ ( $>>0,05)$, порівняно з інтактними тваринами. У наступних кількох термінах було невелике зростання його вмісту у сечі: на 14 добу показник був у межах 100,93 \% (p>0,05), на 21 добу - 102,80\% $(p>0,05)$, на 30 добу спостерігалося найвище зростання його вмісту, яке склало лише 103,73 \% ( $>>0,05)$. Надалі спостерігалось падіння вмісту БЗО до показника фізіологічної норми на 90 добу $(100,93 \% ; p>0,05)$ та подальше зменшення до $98,31 \%(p>0,05)$ у завершальному терміні експерименту (180 доба).
Схожу динаміку, проте з іншими цифровими показниками, отримано у тварин 1 дослідної групи. Дані на 7 добу практично не відрізнялися від інтактних тварин та склали 99,62 \% (p>0,05). У всі наступні терміни виявлено достовірне зростання Вмісту БЗО у сечі, яке складало на 14 добу 106,91 \% $(p<0,05)$, на 21 добу $-114,57 \%(p<0,05)$ та зберігалося у цих межах $(114,99 \% ; p<0,05)$ до 30 доби. у тварин цієї групи достовірне зростання вмісту БЗО продовжувалося і на 90 добу $(112,14 \%$; $<<0,05)$. Більшими за показники інтактних тварин виявилися результати і на завершення спостереження (180 добу) - вони становили 107,85 \% ( $<<0,05)$.

Помітно відрізнялася динаміка вмісту БЗО від описаної вище лише у тварин 2 дослідної групи. 


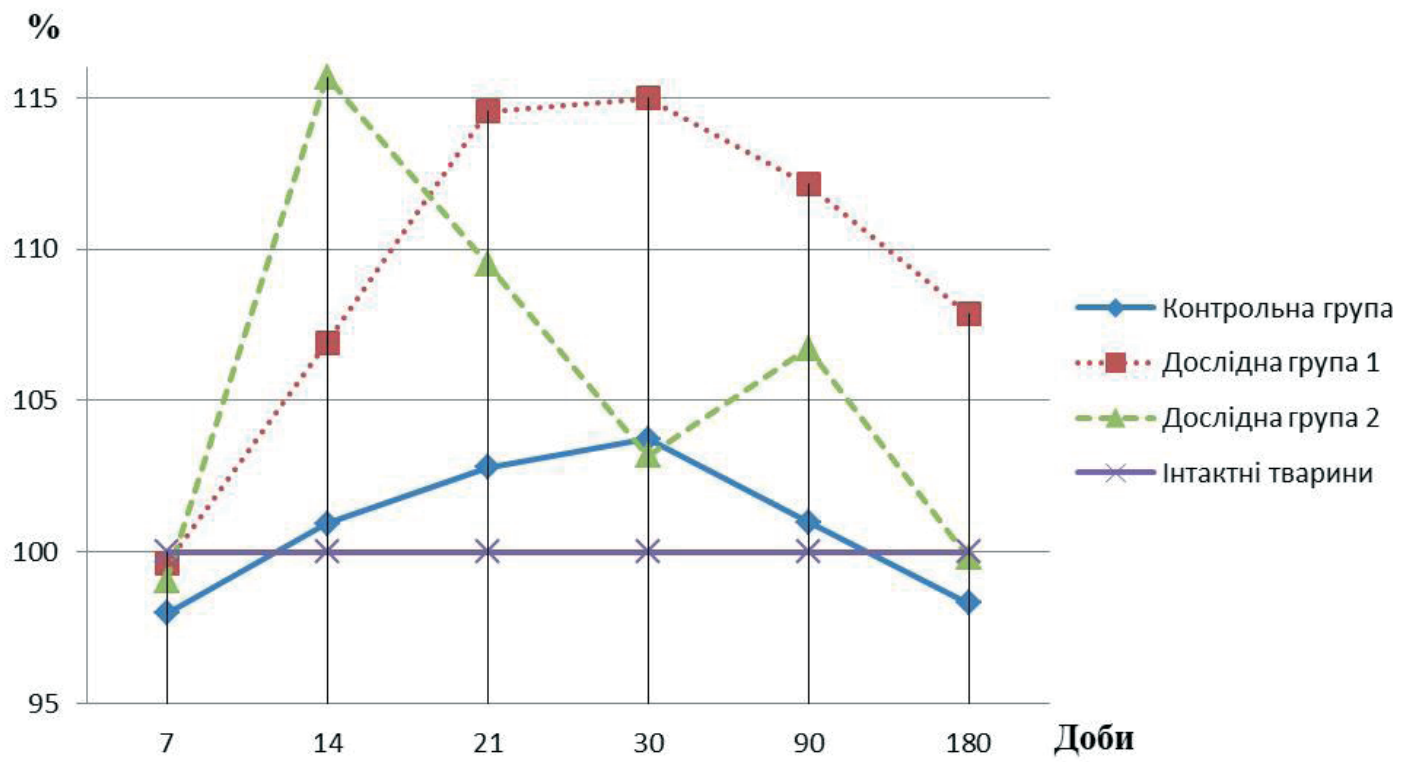

Рис. 2. Динаміка відсоткових значень вмісту білковозв'язаного оксипроліну в сечі експериментальних тварин порівняно з показником інтактних щурів (100\%).

Якщо у початковому терміні дослідження (7 доба) значної відмінності з інтактними тваринами та тваринами інших експериментальних груп виявлено не було $(99,06 \%$ з р>0,05), то вже на 14 добу спостерігали найбільше зростання - до 115,70\% $(p<0,05)$. Починаючи з 21 і до 30 доби вміст БЗО поступово зменшувався та складав, відповідно, $109,33 \%(p<0,05)$ та 103,17 \% $(p<0,05)$ від рівня інтактних тварин.

Особливістю цієї групи було повторне зростання вмісту Б3О на 90 добу до 106,72 \% $(p<0,05)$ та його нормалізація на 180 добу $(99,81 \% ;$ p >0,05).
Оскільки, як вже було зауважено, для фізіологічного та репаративного остеогенезу типовим $€$ поєднання та взаємне врівноваження двох протилежних процесів, а саме анаболізму та катаболізму органічної структури кістки (а це в основному колаген), для динамічної характеристики було використано показник, який їх об'єднував - співвідношення вмісту БЗО до ВО. В інтактних тварин він склав $(0,279 \pm 0,11)$ ум. од. Вирахувані дані для кожної експериментальної групи у кожному терміні представлено у таблиці 3 та на рисунку 3.

Таблиця 3. Співвідношення вмісту білковозв'язаного оксипроліну до вільного (умовні одиниці) у сечі експериментальних тварин $(\mathrm{M} \pm \mathrm{m}, \mathrm{n}=6)$

\begin{tabular}{|c|c|c|c|c|}
\hline \multirow{2}{*}{$\begin{array}{c}\text { Термін } \\
\text { спостереження (доба) }\end{array}$} & \multicolumn{4}{|c|}{ Група тварин } \\
\hline & інтактні & контрольна & дослідна 1 & дослідна 2 \\
\hline 1 & 2 & 3 & 4 & 5 \\
\hline 7 & $0,279 \pm 0,110$ & $\begin{array}{c}0,190 \pm 0,099 \\
p_{1}<0,05\end{array}$ & $\begin{array}{c}0,197 \pm 0,089 \\
\mathrm{p}_{1}<0,05 \\
\mathrm{p}_{2}>0,05\end{array}$ & $\begin{array}{c}0,196 \pm 0,011 \\
\mathrm{P}_{1}<0,05 \\
\mathrm{P}_{2}>0,05 \\
\mathrm{P}_{3}>0,05\end{array}$ \\
\hline 14 & $0,279 \pm 0,110$ & $\begin{array}{c}0,224 \pm 0,095 \\
p_{1}<0,05\end{array}$ & $\begin{array}{c}0,229 \pm 0,160 \\
p_{1}<0,05 \\
p_{2}>0,05\end{array}$ & $\begin{array}{c}0,268 \pm 0,090 \\
\mathrm{P}_{1}>0,05 \\
\mathrm{P}_{2}<0,05 \\
\mathrm{P}_{3}<0,05\end{array}$ \\
\hline 21 & $0,279 \pm 0,110$ & $\begin{array}{c}0,238 \pm 0,163 \\
p_{1}<0,05\end{array}$ & $\begin{array}{c}0,277 \pm 0,209 \\
\mathrm{p}_{1}>0,05 \\
\mathrm{P}_{2}<0,05\end{array}$ & $\begin{array}{c}0,284 \pm 0,125 \\
\mathrm{p}_{1}>0,05 \\
\mathrm{p}_{2}<0,05 \\
\mathrm{p}_{3}>0,05\end{array}$ \\
\hline 30 & $0,279 \pm 0,110$ & $\begin{array}{c}0,247 \pm 0,173 \\
p_{1}<0,05\end{array}$ & $\begin{array}{c}0,304 \pm 0,143 \\
\mathrm{P}_{1}<0,05 \\
\mathrm{P}_{2}<0,05\end{array}$ & $\begin{array}{c}0,272 \pm 0,126 \\
\mathrm{P}_{1}>0,05 \\
\mathrm{P}_{2}>0,05 \\
\mathrm{P}_{3}<0,05\end{array}$ \\
\hline
\end{tabular}




\begin{tabular}{|c|c|c|c|c|}
\hline 1 & 2 & 3 & 4 & 5 \\
\hline 90 & $0,279 \pm 0,110$ & $0,270 \pm 0,135$ & $0,257 \pm 0,156$ & $0,289 \pm 0,127$ \\
& & $\mathrm{P}_{1}>0,05$ & $\mathrm{P}_{1}<0,05$ & $\mathrm{P}_{1}>0,05$ \\
& & & $\mathrm{P}_{2}>0,05$ & $\mathrm{P}_{2}<0,05$ \\
& & & $\mathrm{P}_{3}<0,05$ \\
\hline 180 & $0,279 \pm 0,110$ & $0,273 \pm 0,122$ & $0,259 \pm 0,134$ & $0,277 \pm 0,091$ \\
& & $\mathrm{P}_{1}>0,05$ & $\mathrm{P}_{1}<0,05$ & $\mathrm{P}_{1}>0,05$ \\
& & $\mathrm{P}_{2}>0,05$ & $\mathrm{P}_{2}>0,05$ \\
& & & $\mathrm{P}_{3}>0,05$ \\
\hline
\end{tabular}

Примітки: 1. р 1 - значення коефіцієнта достовірності порівняно з групою інтактних тварин; 2. $\mathrm{p}_{2}$ - значення коефіцієнта достовірності порівняно з контрольною групою;

3. $p_{3}$ - значення коефіцієнта достовірності порівняно з дослідною групою 1.

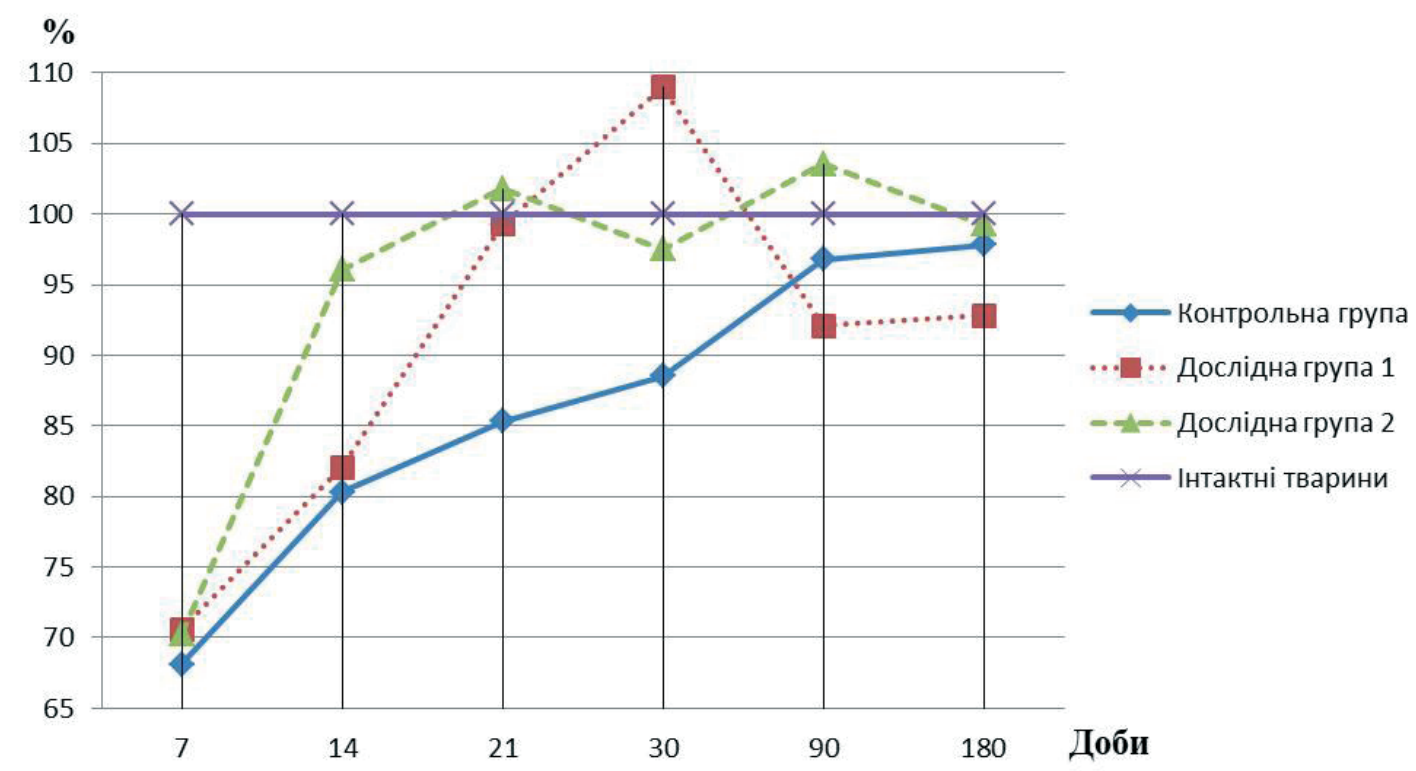

Рис. 3. Динаміка відсоткових значень співвідношення вмісту білковозв'язаного оксипроліну до вільного в сечі експериментальних тварин, порівняно з показником інтактних щурів (100\%).

На 7 добу у тварин контрольної групи було виявлено падіння цього показника до $68,10 \%$ $(p<0,05)$ рівня інтактних тварин. У всі інші терміни значення цього показника поступово зростало. Так, на 14 добу воно становило вже 80,28 \% $(p<0,05)$, на 21 добу $-85,30 \%(p<0,05)$, а на 30 добу$88,53 \%(p<0,05)$. Як бачимо, у ці терміни різниця 3 інтактними тваринами все ще зберігалася достовірною.

Вперше рівень статистичної недостовірності результатів, порівняно з фізіологічними показниками у тварин контрольної групи, виявлено лише на 90 добу і він дорівнював 96,77\% (р>0,05). На завершення спостереження (180 доба) співвідношення обох фракцій оксипроліну склало 97,89 \% $(p>0,05)$.

У тварин 1 дослідної групи на 7 добу падіння досліджуваного показника дорівнювало 70,60 \% $(\mathrm{p}<0,05)$. У наступних трьох термінах було виявлено його зростання. Якщо на 14 добу $(82,78$ \% 3 p $<0,05)$ він ще достовірно різнився, порівняно 3 інтактними тваринами, то вже на 21 добу $(99,28 \%$ 3 p $>0,05)$ ця різниця була недостовірною у статистичному аспекті. Зростання над рівнем фізіологічного показника у цій експериментальній групі виявлено лише на 30 добу, коли його значення досягло $108,96 \%$ ( $<<0,05)$. У завершальні два терміни надалі спостерігалося падіння цього значення достовірно нижче рівня інтактних тварин до $92,11 \%(p<0,05)$ та $92,89 \%(p<0,05)$ відповідно на 90 та 180 доби.

Аналогічно до описаних вище даних, на 7 добу у тварин 2 дослідної групи було достовірне падіння показника співвідношення фракцій оксипроліну до $70,25 \%(p<0,05)$. У наступні два терміни спостерігалася перша хвиля зростання значення цього показника. Вже на 14 добу виявлено статистично недостовірну різницю з фізіологічним показником $(96,05 \% ; р>0,05)$. Незначне зростання спостерігалося на 21 добу, яке досягало 101,79 \% (р>0,05). 
Огляди літератури, оригінальні дослідження, погляд на проблему

Значення цього показника на 30 добу у тварин 2 дослідної групи спадало до 97,49 \% (p>0,05), а на 90 добу повторно зростало до 103,38 \% (р>0,05). На 180 добу виявлено нормалізацію у співвідношенні оксипролінів (99,28 \%; р>0,05).

При огляді рентгенограм на 180 добу експерименту у контрольної групи тварин відмічено, що межі дефекту втрачають чіткість, але візуалізуються та $є$ більш рентгеноконтрастними в периферійних його ділянках, що може свідчити про формування замикаючої компактної пластини. Порожнина виповнена вуаллю, але низької контрастності, вона ще чітко відрізняється від оточуючих тканин, що свідчить про ії̈ незрілість (рис. 4).

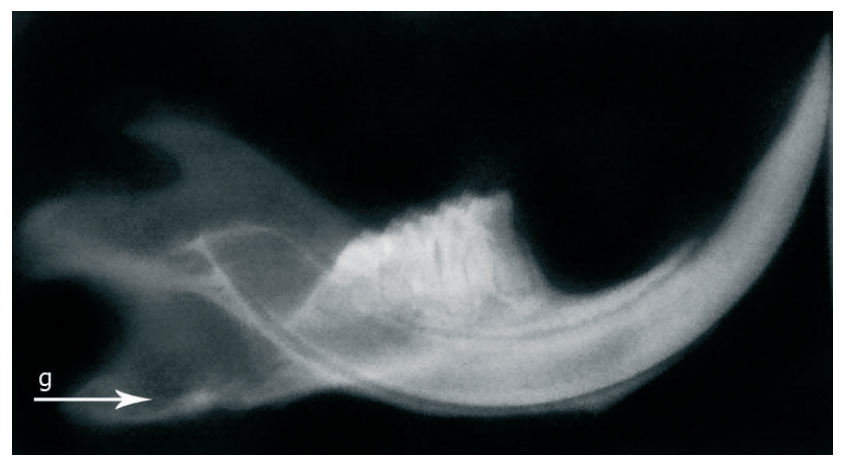

Рис. 4. Рентгенограма нижньої щелепи тварини контрольної групи, 180 доба.

При огляді рентгенограм тварин 1 дослідної групи на 180 добу відмічено, що кістковий дефект не візуалізується, його контури визначити неможливо. Натомість, визначити його колишню ділянку можна за зоною підвищеної рентгеноконтрастності, яка за своєю площею переважає площу модельованого дефекту та свідчить про гіперпродукцію мінералізованих тканин. Ділянка остеосклерозу практично однорідна, трабекули та кісткові порожнини визначити ще неможливо, що свідчить про незавершеність процесів ремодуляції первинної кісткової мозолі (рис. 5).

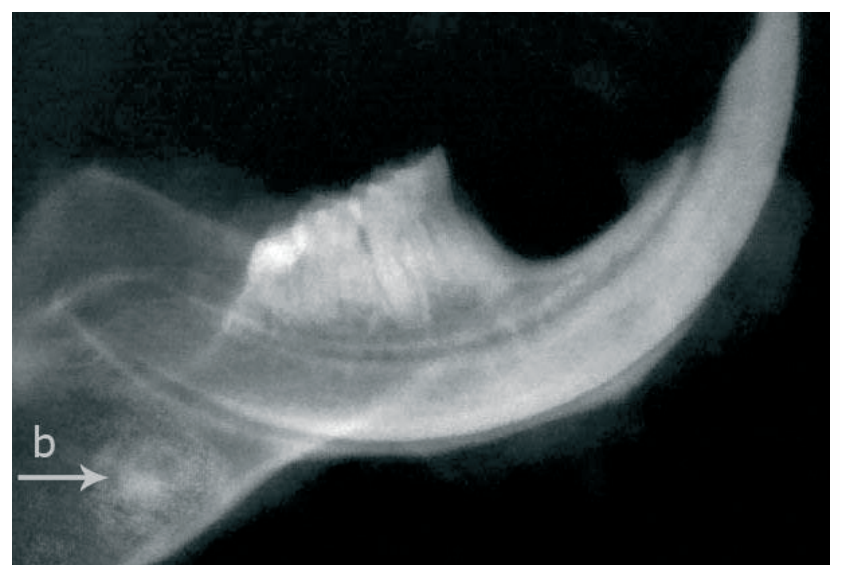

Рис. 5. Рентгенограма нижньої щелепи тварини 1 дослідної групи, 180 доба.
На рентгенограмах нижньої щелепи тварин 2 дослідної групи на 180 добу дослідження регенерат відновлює усю порожнину, визначити межі дефекту практично неможливо, проте він має неоднорідну контрастність. У зоні дефекту чітко визначається сітка кісткових трабекул з ділянками, сформованими кістковомозковими порожнинами. Але подекуди спостерігаються краплиноподібні включення підвищеної інтенсивності, що, очевидно, є залишками остеоімплантата (рис. 6).

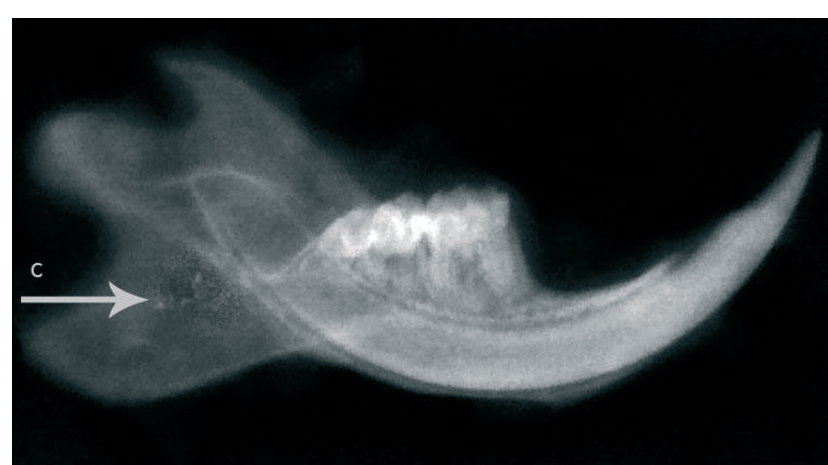

Рис. 6. Рентгенограма нижньої щелепи тварини 2 дослідної групи, 180 доба.

Висновки. 3 отриманих даних дослідження вмісту обох фракцій оксипролінів та їх динамічного співвідношення випливає, що в усіх випадках безпосередньо після нанесеного пошкодження відбуваються процеси деструкції з руйнуванням органічного матриксу кістки. Його тривалість у середньому складає до 7 днів. У випадку значного об'єму пошкодження, як це моделювалося на нижніх щелепах щурів, процеси деструкції домінують над процесами синтезу білкового компонета матриксу - колагену, що відображається у зростанні фракції вільного оксипроліну у сечі впродовж значного періоду часу (до 30 днів), а збалансованість катаболізму та анаболізму спостерігається лише на 180 добу.

Заповнення кісткових дефектів запропонованими остеоімплантатами змінює перебіг регенерації.

У 1 дослідній групі переважання синтетичних процесів над деструкцією відмічається на 30 добу, а у віддалені терміни (90 та 180 доба) надалі відбувається домінування процесу катаболізму над анаболізмом, що, ймовірно, пов'язано із інтенсивним ремоделюванням кісткового рубця.

У 2 дослідній групі домінування процесів синтезу колагену пришвидшується та відмічається вже на 21 добу. Також пришвидшуються процеси ремодуляції та утворення вторинного кісткового регенерату (у середньому на 90 добу), а кінцеве завершення остеорегенерації спостерігається на 180 добу.

Дані, отримані при оцінці рентгенограм нижніх щелеп тварин, повністю корелювали з даними біохімічного дослідження: 
Огляди літератури, оригінальні дослідження, погляд на проблему

Перспективи подальших досліджень. Планується вивчення взаємозв'язків з іншими біохімічними маркерами регенерації та проведення кореляції отриманих даних з даними морфологічного та морфометричного досліджень.

\section{ЛІТЕРАТУРА}

1. Альфаро Ф. Э. Костная пластика в стоматологической имплантологии / Ф. Э. Альфаро. - М. : Издательство «Азбука», 2006. - 235 с.

2. Столяров М. В. Оценка восстановления челюстной кости после зубосохраняющих операций с организацией в ране кровяного сгустка / М. В. Столяров, Л. А. Любовцева, Н.В.Кандейкина // Фундаментальные исследования. - 2014. - № 10. - С. 1979-1983.

3. Афанасьев В. В. Хирургическая стоматология : учебник / [Афанасьев В. В. и др.]; под. общ. ред. В. В. Афанасьева. - М. : ГЭОТАР-Медиа, 2010.- 880 с.

4. Панкратов А. С. Костная пластика в стоматологии и челюстно-лицевой хирургии. Остеопластические материалы : [руководство для врачей] / А. С. Панкратов, М. В. Лекишвили, И. С. Копецкий. - М. : Издательство БИНОМ, 2011.- 272 с.

5. Современное состояние вопроса о костнопластических материалах стимулирующих остеогенез / И. П. Ардашев, С. В. Черницов, И. Ю. Веретельникова [и др.] // Вестник новых медицинских технологий. 2011. - T. XVIII, № 4. - С. 161-165.

6. Гизатулин Р. А. Средства для оптимизации остеогенеза в стоматологи: область применения, актуальность проблемы и перспективы разработок и внедрения новых препаратов / Р. А. Гизатулин.- М., 2007. $152 \mathrm{c}$.

7. Ирьянов Ю. М. Современные представления о гистологических аспектах репаративной регенерации костной ткани. Клеточные источники репаративного остеогенеза. Гетерогенность клеточной популяции в области травматического повреждения кости / Ю. М. Ирьянов, Т. А. Силантьева // Гений ортопедии. - № 2. - 2007. С. $111-116$.

\section{REFERENCES}

1. Alfaro, F.E. (2006). Kostnaya plastika v stomatologicheskoy implantologii [Bone plastic surgery in dental implantology]. Rukovodstvo. Izdatelstvo: "Azbuka” [in Russian].

2. Stolyarov, M.V., Lyubovtseva, L.A. \& Kandeykina, N.V. (2014). Otsenka vosstanovleniya chelyustnoy kosti posle zubosokhranyayushchikh operatsíy s organizatsiyey $v$ rane krovyanogo sgustka [Evaluation of the restoration of the jawbone after the tooth-preserving operations with the organization in the wound of a blood clot]. Fundamentalnyye issledovaniya - Fundamental Research, 10, 1979-1983 [in Russian].

3. Afanasyev, V.V. (2010). Khirurgicheskaya stomatologiya [Surgical dentistry]. Uchebnik. Moscow: GEOTARMedia [in Russian].

4. Pankratov, A.S., Lekishvili, M.V. \& Kopetskiy, I.S. (2011). Kostnaya plastika v stomatologii i chelyustno-litsevoy khirurgii. Osteoplasticheskiye materialy (rukovodstvo dlya vrachey) [Bone plastic surgery in dentistry and maxillo-
8. Волова Т. Г. Материалы для медицины, клеточной и тканевой инженерии : учебное пособие / Т. Г. Волова, Е. И. Шишацкая, П. В. Миронов. - Красноярск : ИПК СФУ, 2009. - 262 с.

9. Hassan M. G. Vertical and horizontal bone augmentation with the intraoral autogenous J-graft / M. G. Hassan // Implant Dentistry. -2009. - Vol. 18, No. 3. - P. 230-238.

10. Kao R. T. Tissue engineering for periodontal regeneration/R.T.Kao//J. Calif.Dent. Assoc.-2005.-Vol.33(3).P. 205-215.

11. Kfir E. Minimally invasive guided bone regeneration / E. Kfir, V. Kfir, E. Kaluski // J. Oral Implantol. - 2007. Vol. 33 (4). - P. 205-210.

12. The biology of bone grafting/S. N. Khan, F. P. Cammisa, H. S. Sandhu [et al.] // J. Am. Acad. Orthop. Surg. 2005. - № 13 (1). - P. 77-86.

13. Retzepi M. Guided Bone Regeneration: biologic principles and therapeutic applications / M. Retzepi, N. Donos // Clin. Oral Impl. Res. - 2010. - Vol. 21. - P. 567-576.

14. Ramin Rohanizadeh. Hydroxyapatite as a carrier for bone morphogenetic protein / Ramin Rohanizadeh, Kimberly Chung // Journal of Oral Implantology. - 2011. - Vol. 37 (6). P. 659-672.

15. Шараев П. Н. Метод определения свободного и связанного оксипролина в сыворотке крови / П. Н. Шараев // Лаб. Дело. - 1981. - № 5. - С. 284-285.

16. Северин Е. С. Биохимия с упражнениями и задачами : учебник для вузов / под ред. чл.-кор. РАН Е. С. Северина. - М. : ГОЭТАР-Медиа. - 2010. - 384 с.

17. Функціональна біохімія сполучної тканини : навч.-метод. посібник для студ. 2 курсу / Л. Д. Попова, В. І. Жуков, Т. В. Горбач та ін.; за ред. В. І. Жукова. -Харків: XHMY, 2011. -93 C.

facial surgery. Osteoplastic materials (manual for doctors)]. Moscow: Izdatelstvo BINOM, 272 [in Russian].

5. Ardashev, I.P., Chernitsov, S.V., Veretelnikova, I.Yu., Hrishanov, A.A. \& Shpakovskyy, M.S. (2011). Sovremennoye sostoyaniye voprosa o kostnoplasticheskikh materialakh stimuliruyushchikh osteogenez [The current state of the issue of osteoplastic materials stimulating osteogenesis]. Vestnik novykh meditsinskikh tekhnologiy - Journal of New Medical Technologies, (XVIII), 4, 161-165 [in Russian].

6. Gizatulin, R.A. (2007). Sredstva dlya optimizatsii osteogeneza $v$ stomatologi: oblast primeneniya, aktualnost problemy i perspektivy razrabotok $i$ vnedreniya novykh preparatov [Means for optimizing osteogenesis in dentists: the field of application, the urgency of the problem and the prospects for the development and introduction of new drugs]. Moscow [in Russian].

7. Iryanov, Yu.M. \& Silantyeva, T.A. (2007). Sovremennyye predstavleniya o gistologicheskikh aspektakh repara- 
Огляди літератури, оригінальні дослідження, погляд на проблему

tivnoy regeneratsii kostnoy tkani. Kletochnyye istochniki reparativnogo osteogeneza. Geterogennost kletochnoy populyatsii v oblasti travmaticheskogo povrezhdeniya kosti [Modern ideas about the histological aspects of reparative bone tissue regeneration. Cell sources of reparative osteogenesis. Heterogeneity of the cell population in the field of traumatic bone injury]. Geniy ortopedii - Genius of Orthopedics, 2, 111-116 [in Russian].

8. Volova, T.G., Shishatskaya, Ye.I. \& Mironov, P.V. (2009). Materialy dlya meditsiny, kletochnoy i tkanevoy inzhenerii. Uchebnoye posobiye [Materials for medicine, cellular and tissue engineering: textbook]. Krasnoyarsk: IPK SFU [in Russian].

9. Hassan, M.G. (2009). Vertical and horizontal bone augmentation with the intraoral autogenous J-graft. Implant dentistry, (18), 3, 230-238.

10. Kao, R.T. (2005). Tissue engineering for periodontal regeneration. J. Calif. Dent. Assoc., (33) 3, 205-215.

11. Kfir, E., Kfir, V. \& Kaluski, E. (2007). Minimally invasive guided bone regeneration. J. Oral Implantol., (33), 4, 205-210.

12. Khan, S.N., Cammisa, F.P., Sandhu, H.S., Diwan, A.D., Girardi, F.P. \& Lane, J.M. (2005). The biology of bone grafting. J. Am. Acad. Orthop. Surg., 13 (1), 77-86.

13. Retzepi, M. \& Donos, N. (2010). Guided Bone Regeneration: biologic principles and therapeutic applications. Clin. Oral Impl. Res., (21), 567-576.

14. Ramin Rohanizadeh \& Kimberly Chung (2011). Hydroxyapatite as a carrier for bone morphogenetic protein. Journal of Oral Implantology, 37 (6), 659-672.

15. Sharayev, P.N. (1981). Metod opredeleniya svobodnogo i svyazannogo oksiprolina v syvorotke krovi [Method for determination of free and bound hydroxyproline in blood serum]. Lab. Delo-Lab. Case, 5, 284-285 [in Russian].

16. Severin, Ye.S. (Ed.) (2010). Biokhimiya s uprazhneniyami i zadachami: uchebnik dlya vuzov [Biochemistry with exercises and tasks: a textbook for universities]. Moscow: GOETAR-Media [in Russian].

17. Popova, L.D., Zhukov, V.I., Horbach, T.V., Shcherban, M.H., Vasylyeva, I.M., Haluzinska, L.V. ... Zhukov, V.I. (Eds.) V.I. Zhukova. (2011). Funktsionalna biokhimiia spoluchnoi tkanyny: Navch.-metod. posibnyk dlia stud. 2 kursu [Functional biochemistry of connective tissue: Teaching method. Tutorial for the studio. 2 course]. Kharkiv: KHNMU [in Ukrainian].

\title{
СРАВНИТЕЛЬНАЯ ХАРАКТЕРИСТИКА ПРОЦЕССОВ ОСТЕОРЕГЕНЕРАЦИИ ПРИ ИСПОЛЬЗОВАНИИ МАТЕРИАЛА НА ОСНОВЕ ГИДРОКСИАПАТИТА И ПОЛЛИЛАКТИДА
}

๑О. В. Скочило

\author{
Гвуз «Тернопольский государственный медицинский университет имени. И. Я. Горбачевского \\ МЗ Украины»
}

РЕЗЮМЕ. Вступление. Остеорегенерация при восстановлении костных дефектов челюстей является важным вопросом современной стоматологии. Несмотря на многочисленные работы, идеального материала все еще не существует, поэтому его поиск является актуальным.

Цель исследования. Изучение процессов остеорегенерации путем оценки маркеров обмена коллагена и проведение сравнительного анализа репарации в корреляции с рентгенологическимu даннымU на 180 сутки эксперимента.

Материал и методы. Эксперимент проведен на белых крысах-самцах массой 180-200 г. Под общим обезболиванием животным создавали сквозное отверстие в области челюсти. В контрольной группе заживление происходило только под кровяным свертком, а в опытных группах костный дефект восстанавливался материалом на основе гидроксиапатита и поллилактида с различным процентным содержанием компонентов (1 группа (80:20 \%); 2 группа (50:50 \%)); отдельно выделена группа интактных животных, которым вмешательство не проводилось, а лишь осуществлялся забор мочи для сравнительного исследования.

Рентгенологическое исследование изъятых челюстей проводили с помощью цифрового радиовизиографа Intra (Финляндия).

Результаты. Во всех случаях после повреждения происходят процессы деструкции, продолжающиеся до 7 суток. В контрольной группе наблюдается медленная их обратная тенденция, а сбалансирование происходит на 90 день, достижения физиологического гомеостаза - на 180 сутки. В 1 опытной группе преобладание синтетических процессов над деструкцией отмечается на 30 сутки, а в отдаленные сроки (90 и 180 сутки) в дальнейшем происходит доминирование процесса катаболизма над анаболизмом. Во 2 опытной группе доминирование процессов синтеза коллагена ускоряется и отмечается уже на 21 сутки, а конечное завершение остеорегенерации наблюдается на 180 сутки. Данные, полученные при оценке рентгенограмм нижних челюстей животных, коррелировали с данными биохимического исследования.

Выводы. Заполнение костных дефектов предложенными остеоимплантатами меняет ход регенерации. Установлено, что заполнение дефекта резорбирующим композитом уменьшает деструктивные процессы и ускоряет формирование первичной и вторичной костной мозоли. В этом отношении более эффективной оказалась композиция с одинаковым содержанием обеих ее составляющих.

КЛЮЧЕВЫЕ СЛОВА: костный дефект; регенерация костной ткани; гидроксиапатит; поллилактид; свободный оксипролин; белковосвязаный оксипролин. 


\section{COMPARATIVE CHARACTERISTIC OF OSTEOREGENERATION PROCESSES USING THE MATERIAL ON THE BASIS OF HYDROXYAPATITE AND POLYLACTIDE}

\section{O. V. Skochylo}

\section{Horbachevsky Ternopil State Medical University}

SUMMARY. Introduction. Bone regeneration in restoring bone defects of jaws is an important issue in modern dentistry. A large number of articles confirm that the ideal material does not exist yet and its search is relevant.

The aim of the study. Study of osteorecreasing processes by evaluating collagen exchange markers and conducting a comparative analysis of reparation in correlation with X-ray data for 180 days of the experiment.

Materials and Methods. The experiment was conducted on white male rats weighing 180-200 g. Under general anesthesia, animals created a through hole in the jaw area. In the control group, treatment was performed only with blood convection. In the experimental groups, the bone defect was replaced with a material based on hydroxyapatite and polyllactics with different percentages of components (group 1 (80\%: $20 \%$ ) and group 2 (50\%: 50\%)), and a separate group of intact animals that was subjected to urine sampling for comparative study.

X-ray examination of the removed jaws was carried out with the help of a digital radio-visualographer Intra (Finland).

Results and Discussion. In all cases, after trauma, there are destruction processes that last up to 7 days. In the control group there is a slow reversal of their tendency, and balancing occurs only for 90 days, the achievement of physiological homeostasis - by 180 days.

In the research group 1, the predominance of synthetic processes over destruction is noted for 30 days, and in the long term (90 and 180 days), the dominance of the process of catabolism over anabolism continues to prevail.

In the experimental group 2, the domination of collagen synthesis processes is accelerated and marked for 21 days, and the final completion of osteoreceptor is observed for 180 days.

The results of $\mathrm{X}$-ray examinations correlated with the biochemical results of the study.

Conclusions. The filling of bone defects by the proposed osteoimplants changes the course of regeneration. It was established that filling the defect with a resorbable composite reduces destructive processes and accelerates the formation of the primary and secondary bone mosaic. In this respect, the composition with the same content of both its components was more effective.

KEY WORDS: bone defect; bone tissue regeneration; hydroxyapatite; polylactide; free oxyproline; protein synthesizing oxyproline. 